\title{
Epidemiology of Collar Rot of Sunflower (Helianthus annus L.) caused by Sclerotium rolfsii Sacc.
}

\author{
Vishal Gandhi ${ }^{{ }^{*}}$, R. S. Taya and Anil Kumar \\ Department of Plant Pathology, Chaudhary Charan Singh Haryana Agricultural University, \\ Hisar-125 004, Haryana, India \\ *Corresponding author
}

\section{A B S T R A C T}

\section{Keywords}

Sclerotium rolfsii, Sunflower,

Epidemiology,

Correlation,

Regression

Article Info

Accepted: 07 September 2019 Available Online: 10 October 2019
Collar rot disease caused by Sclerotium rolfsii Sacc. is one of the most important disease of sunflower in India. In the changing climate, this disease in sunflower has been recognized as a major threat in causing more economic loss than before. Environmental parameters such as relative humidity, temperature, bright sunshine hours and rainfall have been shown to influence infection and subsequent damage caused by $S$. rolfsii. Keeping this in view, experiment on epidemiology of collar rot of sunflower (Helianthus annus L.) caused by Sclerotium rolfsii Sacc. was conducted under field conditions at research farm of CCS, Haryana Agricultural University, Hisar in 2014-2015.The maximum disease incidence was found during $1^{\text {st }}$ date of sowing followed by $3^{\text {rd }}$ date of sowing on two different hybrids HSFH-1183 and Pioneer 64A57 varied from 30.6-36.4 per cent and least disease incidence was recorded during $2^{\text {rd }}$ date of sowing varied from 19.8-21.8 per cent on the same hybrids. Present investigations indicate that sunflower sown by mid July was good to protect the crop from collar rot disease under present conditions. Correlation matrix for the development of collar rot disease in relation to weather variables also revealed that minimum temperature had negative and significant correlation with the disease incidence in both hybrids and during all the three dates of sowing, whereas relative humidity morning had negative and significant correlation during third date of sowing, but negative and non significant correlation during first two dates of sowing. Rainfall had negative but non significant correlation with the disease incidence. Maximum temperature had positive and non significant correlation with the disease incidence during first two dates of sowing but positive and significant correlation during $3^{\text {rd }}$ date of sowing in both hybrids. Sunshine hours had also positive and non significant correlation with the disease incidence during $1^{\text {st }}$ and $2^{\text {nd }}$ date of sowing, but positive and significant correlation during $3^{\text {rd }}$ date of sowing in both hybrids.

\section{Introduction}

Sunflower (Helianthus annus L.) is one of the important oilseed crops in India, which belongs to the family Compositae. In India it is grown in area of 0.83 million hectares with production of 0.54 million tonnes (Anonymous, 2013). Diseases are one of the 
important factors limiting the productivity of sunflower crop. Among them collar rot disease caused by Sclerotium rolfsii Sacc. is one of the most important disease of sunflower. In the changing climate, this disease in sunflower has been recognized as a major threat in causing more economic loss than before. The fungus, $S$. rolfsii Sacc. is a well-known polyphagous, ubiquitous, omnivorous and most destructive soil borne pathogen. The yield loss caused by this pathogen is $10-25$ per cent, but sometimes it reaches 80-90 per cent (Grichar and Bosweel, 1987). In India, collar rot caused by $S$. rolfsii is a major problem in most of the states accounting for 10-11 per cent yield loss (Prasad et al., 2012). The typical symptoms of this disease are rapid wilting and sickly appearance of plants with brownish lesion at the stem base near the soil level which later girdles the stem. White mycelial growth forms over the infected tissue and often radiates over the soil surface. The production of abundant white mycelium and small brown spherical sclerotia on the infected parts are characteristic symptoms of the disease. The fungus does not produce asexual spores and perpetuates as sclerotia on plant debris and in soil (Chillers $e t$ al., 2000).

The spatial pattern of inoculum of $S$. rolfsii in naturally infested fields was clustered or clumped (Punja et al., 1985; RodriguezKabana et al., 1974). Disease incidence due to $S$. rolfsii may increase following periods of temperature and moisture fluctuations; cycles of drying and wetting have been reported to stimulate germination of sclerotia (Smith, 1972; Punja and Grogan, 1981). Punja (1985) reported that temperatures and moist conditions appear to enhance disease development. Initial infection occurs at soil level, where sclerotia was most likely to be stimulated to germinate by drying and remoistening (Punja and Grogan, 1981). Free moisture was apparently not required for infection (Punja and Jenkins, 1984). Among factors influencing the survival of sclerotia include temperature, moisture, and biotic factors such as soil microorganisms near sclerotia (Punja, 1985). Temperatures above $50^{\circ} \mathrm{C}$ for extended periods are lethal to sclerotia (Porter and Merriman, 1983; Mihail and Alcorn, 1984). There were generally fewer sclerotia in moist than in dry soil (Bandara, 1980; Beute and Rodriguez-Kabana, 1981). However, high temperatures coupled with high soil moisture were more detrimental to survival than are high temperatures alone (Beute and Rodriguez-Kabana, 1981). Sclerotia survive better in moist soil near the surface rather than buried (Beute and Rodriguez-Kabana, 1981; Javed and ColeySmith, 1973).

Although much effort has been placed on defining the optimal environmental conditions for the development of collar rot disease, the exact conditions that drive epidemics of the disease are still unknown. Environmental parameters such as relative humidity, temperature, soil moisture and soil $\mathrm{pH}$ have been shown to influence infection and subsequent damage caused by S. rolfsii (Punja, 1985).

The pathogen survives at temperatures ranging from $8-40^{\circ} \mathrm{C}$, although infections have been shown to be reduced at temperatures below $20^{\circ} \mathrm{C}$ and above $35^{\circ} \mathrm{C}$ (Aycock, 1966, Mehan et al., 1995). However, optimal soil temperature for $S$. rolfsii infection has been cited as $30^{\circ} \mathrm{C}$ for most cropping systems (Aycock, 1966).Meager information is available in the literature with regard to the effect of weather factors on the disease development.

Hence the present studies was carried out to investigate the epidemiology of collar rot of sunflower (Helianthus annus L.) caused by $S$. rolfsii Sacc. 


\section{Materials and Methods}

To study the role of environmental factors on disease incidence

Two hybrids Pioneer 64A57 \& HSFH 1183 of sunflower were planted in RBD design with three replication in plot size $5 \times 5 \mathrm{~m}^{2}$. The sowing was done on three dates viz., June 30 , 2014 as first date of sowing, second on July15, 2014 and third date of sowing July 31, 2014.

\section{Disease incidence}

Disease incidence was recorded in two hybrids sown at three different dates. Disease incidence was recorded after the initiation of the disease of each hybrid at weekly interval till the harvest of the crop. The disease incidence was correlated with prevailing weather parameters such as minimum temperature, maximum temperature, relative humidity morning, relative humidity evening, bright sunshine and rainfall obtained from the Observatory, Department of AgroMeteorology CCS Haryana Agricultural University Hisar. The data were analyzed for correlation and regression coefficients. The prediction equation used was $\mathrm{Y}=\mathrm{a}+\mathrm{b}_{1} \mathrm{X}_{1}+$ $\mathrm{b}_{2} \mathrm{X}_{2}+\ldots \mathrm{b}_{6} \mathrm{X}_{6}$ where $\mathrm{Y}=$ predicted disease incidence, $a=$ intercept, $b_{1}$ to $b_{6}=$ regression coefficient, $\mathrm{X}_{1}$ to $\mathrm{X}_{6}=$ independent variables, $\mathrm{X}_{1}=$ minimum temperature $\left({ }^{0} \mathrm{C}\right), \quad \mathrm{X}_{2}=$ maximum temperature $\left({ }^{0} \mathrm{C}\right), \quad \mathrm{X}_{3}=$ relative humidity morning $(\%), \mathrm{X}_{4}=$ relative humidity evening (\%), $\mathrm{X}_{5}=$ bright sun shine (hours), $\mathrm{X}_{6}=$ rainfall $(\mathrm{mm})$.

\section{Results and Discussion}

\section{Effect of environmental factors on the disease incidence of collar rot in sunflower}

Collar rot incidence on two different hybrids of sunflower was influenced by variation and interaction of different environmental factors under field conditions. The different weather variables viz., maximum temperature (Max. Temp.), minimum temperature (Min. Temp.), relative humidity morning (RHM), relative humidity evening (RHE), Bright Sunshine (BSS) and rainfall were undertaken to evaluate the role of these factors in the epidemic development of disease under field conditions. Two sunflower hybrids viz., HSFH-1183 and Pioneer 64A57 were sown on three dates viz., 30 June, 2014, 15 July, 2014 and 1 August 2014. The disease incidence was recorded after initiation at weekly intervals. The data on different aspects are presented here.

\section{Disease incidence on different dates of sowing}

The disease incidence of collar rot on different sunflower hybrids sown on different dates was recorded. The results presented in table 1. A revealed that the disease incidence of collar rot of sunflower varied from 30-36 per cent and was maximum on hybrid HSFH-1183 (36.4\%) followed by Pioneer 64A57 (30.6\%) during first date of sowing.

In the second date of sowing, data presented in table 2 revealed that the disease incidence varied from 19-22 per cent and was maximum on the hybrid HSFH-1183 (21.8\%) followed by Pioneer 64A57 (19.8\%).

In the third date of sowing, data presented in Table 3 revealed that the disease incidence varied from 31-35 per cent and was maximum on hybrid HSFH-1183 (35.1\%) followed by Pioneer 64A57 (31.9\%). The results revealed that the collar rot incidence increased from 3036 per cent when the crop sown in last week of June and 31-35 per cent when the crop sown in last week of July. However, decrease in disease incidence was from 19-22 per cent when the crop sown in second week of July. The varietal behaviour on the development of collar rot were also recorded and observed that both 
hybrids were susceptible to collar rot and there was no variation in the development of collar rot in respect to varietal behavior (Fig. 1-3).

\section{Correlation analysis}

The correlation coefficient between collar rot disease and weather variables $\left(\mathrm{X}_{1}, \mathrm{X}_{2}, \mathrm{X}_{3}, \mathrm{X}_{4}\right.$, $\mathrm{X}_{5}$ and $\mathrm{X}_{6}$ ) during different dates of sowing are presented in table 4.

The data presented in table 4 revealed that some of the weather parameters significantly influenced the collar rot disease incidence during different dates of sowing. Among the weather variables minimum temperature was most important for collar rot disease spread during all the three dates of sowing as indicated by correlation coefficient which are highly significant and ranged from 0.96 to 0.98 .

During the first date of sowing (last week of July) minimum temperature had a negative and significant correlation with the disease incidence in both the hybrids. Maximum temperature and bright sun shine had a positive but non significant correlation with disease incidence in both hybrids. Relative humidity evening and rainfall had a negative and non significant correlation with disease incidence

During the second date of sowing (second week of July) minimum temperature had also a negative and significant correlation with disease incidence on the two hybrids.

During third date of sowing (last week of July) the weather parameters temperature maximum and sun shine had a positive and significant correlation with disease incidence in both hybrids. Relative humidity evening had a negative and significant correlation with disease incidence.

\section{Regression equation}

The regression equations to quantify the relation to weather variables were developed by using step wise regression analysis.

The regression equations along with $\mathrm{R}^{2}$ are presented in table 5. Minimum temperature and Rainfall contributed up to 98 per cent in the development of disease in both hybrids during first date of sowing in addition to other factors. Minimum temperature also played a major role in the development of collar rot in both hybrids in second date of sowing and it contributed 0.96 per cent in hybrid HSFH1183 and 0.94 per cent in hybrid Pioneer 64A57 in the development of disease during second date of sowing. However, in third date of sowing maximum temperature explained the collar rot variability up to $92-93$ per cent in both hybrids.

The development of disease under field conditions is dependent upon the variation on environmental factors during crop growth period. In the present studies, the sowing at different time period had profound effect on the development of collar rot disease of sunflower. The results revealed that maximum disease incidence was observed during $1^{\text {st }}$ date of sowing (30 June, 2014) followed by $3^{\text {rd }}$ date of sowing (31 July, 2014) on two different hybrids HSFH-1183 and Pioneer 64A57 varied from 30.6-36.4 per cent and least disease incidence was recorded during $2^{\text {nd }}$ date of sowing (15 July, 2014) varied from 19.821.8 per cent on the same hybrids.

The maximum disease incidence of collar rot $(73.33 \%)$ was also recorded in the crop Amorphophallus paeoniifolius sown on $16^{\text {th }}$ May, 2004, whereas, the minimum collar rot incidence i.e. 47.22 per cent was recorded in the crop sown on $28^{\text {th }}$ March, 2004, being at par with $15^{\text {th }}$ March, 2004 and $15^{\text {th }}$ February, 2004 sown crop (Singh et al., 2008). 
Table.1 Disease incidence of collar rot with respect to weather parameters in sunflower under first date of sowing (30 -6-2014)

\begin{tabular}{|c|c|c|c|c|c|c|c|c|}
\hline $\begin{array}{c}\text { Date of } \\
\text { observation }\end{array}$ & $\begin{array}{c}\text { HSFH- } \\
\mathbf{1 1 8 3} \\
(\boldsymbol{\%} \text { D.I. })\end{array}$ & $\begin{array}{c}\text { Pioneer } \\
\mathbf{6 4 A 5 7} \\
(\boldsymbol{\%} \text { D.I. })\end{array}$ & $\begin{array}{c}\text { Max. } \\
\text { Temp. } \\
\left({ }^{\circ} \mathbf{C}\right)\end{array}$ & $\begin{array}{c}\text { Min. } \\
\text { Temp. } \\
\left({ }^{\circ} \mathbf{C}\right)\end{array}$ & $\begin{array}{c}\text { Morning } \\
\text { RH } \\
(\boldsymbol{\%})\end{array}$ & $\begin{array}{c}\text { Evening } \\
\text { RH } \\
(\boldsymbol{\%})\end{array}$ & $\begin{array}{c}\text { BSS } \\
(\mathbf{h r s})\end{array}$ & $\begin{array}{c}\text { Total } \\
\text { Rainfall } \\
(\mathbf{m m})\end{array}$ \\
\hline 01-Aug. & 5.1 & 3.2 & 33.7 & 27.0 & 88.3 & 69.0 & 5.3 & 51.8 \\
\hline 08-Aug. & 9.3 & 5.3 & 35.2 & 27.1 & 89.6 & 62.7 & 5.2 & 33.2 \\
\hline 15-Aug. & 20.4 & 14.6 & 36.1 & 26.7 & 80.1 & 51.9 & 7.2 & 0 \\
\hline 22-Aug. & 31.0 & 25.6 & 36.5 & 26.1 & 76.4 & 43.7 & 8.9 & 0 \\
\hline 29-Aug. & 35.9 & 29.1 & 38.3 & 25.6 & 72.7 & 41.6 & 9.7 & 0 \\
\hline 05-Sep. & 36.4 & 30.6 & 33.4 & 25.4 & 88.7 & 66.9 & 4.9 & 35.4 \\
\hline
\end{tabular}

Table.2 Disease incidence of collar rot with respect to weather parameters in sunflower under second date of sowing (15 -7-2014)

\begin{tabular}{|c|c|c|c|c|c|c|c|c|}
\hline $\begin{array}{c}\text { Date of } \\
\text { observation }\end{array}$ & $\begin{array}{c}\text { HSFH- } \\
\mathbf{1 1 8 3} \\
(\boldsymbol{\%} \text { D.I. })\end{array}$ & $\begin{array}{c}\text { Pioneer } \\
\mathbf{6 4 A 5 7} \\
(\boldsymbol{\%} \text { D.I. })\end{array}$ & $\begin{array}{c}\text { Max. } \\
\text { Temp. } \\
\left({ }^{\circ} \mathbf{C}\right)\end{array}$ & $\begin{array}{c}\text { Min. } \\
\text { Temp. } \\
\left({ }^{\circ} \mathbf{C}\right)\end{array}$ & $\begin{array}{c}\text { Morning } \\
\text { RH }(\boldsymbol{\%})\end{array}$ & $\begin{array}{c}\text { Evening } \\
\text { RH (\%) }\end{array}$ & $\begin{array}{c}\text { BSS } \\
(\mathbf{h r s})\end{array}$ & $\begin{array}{c}\text { Total } \\
\text { Rainfall } \\
(\mathbf{m m})\end{array}$ \\
\hline 22-Aug. & 3.5 & 2.5 & 36.5 & 26.1 & 76.4 & 43.7 & 8.9 & 0 \\
\hline 29-Aug. & 6.9 & 6.0 & 38.3 & 25.6 & 72.7 & 41.6 & 9.7 & 0 \\
\hline 05-Sep. & 7.2 & 6.4 & 33.4 & 25.4 & 88.7 & 66.9 & 4.9 & 35.4 \\
\hline 12-Sep. & 8.1 & 7.3 & 33.8 & 25.9 & 91.3 & 67.1 & 6.2 & 40.6 \\
\hline 19-Sep. & 13.6 & 12.1 & 34.8 & 24.1 & 86.3 & 51.1 & 8.2 & 3.6 \\
\hline 26-Sep. & 21.8 & 19.8 & 36.4 & 22.0 & 77.3 & 37.6 & 10.1 & 0 \\
\hline
\end{tabular}

Table.3 Disease incidence of collar rot with respect to weather parameters in sunflower under third date of sowing (31-7-2014)

\begin{tabular}{|c|c|c|c|c|c|c|c|c|}
\hline $\begin{array}{c}\text { Date of } \\
\text { observation }\end{array}$ & $\begin{array}{c}\text { HSFH- } \\
\mathbf{1 1 8 3} \\
(\mathbf{\% D . I .})\end{array}$ & $\begin{array}{c}\text { Pioneer } \\
\mathbf{6 4 A 5 7} \\
(\boldsymbol{\%} \text { D.I. })\end{array}$ & $\begin{array}{c}\text { Max. } \\
\text { Temp. } \\
\left({ }^{\circ} \mathbf{C}\right)\end{array}$ & $\begin{array}{c}\text { Min. } \\
\text { Temp. } \\
\left({ }^{\circ} \mathbf{C}\right)\end{array}$ & $\begin{array}{c}\text { Morning } \\
\text { RH (\%) }\end{array}$ & $\begin{array}{c}\text { Evening } \\
\text { RH (\%) }\end{array}$ & $\begin{array}{c}\text { BSS } \\
(\mathbf{h r s})\end{array}$ & $\begin{array}{c}\text { Total } \\
\text { Rainfall } \\
(\mathbf{m m})\end{array}$ \\
\hline 05-Sep. & $\mathbf{3 . 4}$ & $\mathbf{2 . 2}$ & 33.4 & 25.4 & 88.7 & 66.9 & 4.9 & 35.4 \\
\hline 12-Sep. & $\mathbf{7 . 6}$ & $\mathbf{5 . 8}$ & 33.8 & 25.9 & 91.3 & 67.1 & 6.2 & 40.6 \\
\hline 19-Sep. & $\mathbf{1 4 . 1}$ & $\mathbf{1 1 . 6}$ & 34.8 & 24.1 & 86.3 & 51.1 & 8.2 & 3.6 \\
\hline 26-Sep. & $\mathbf{2 2 . 1}$ & $\mathbf{1 8 . 7}$ & 36.4 & 22.0 & 77.3 & 37.6 & 10.1 & 0 \\
\hline 03-Oct. & $\mathbf{2 6 . 1}$ & $\mathbf{2 1 . 9}$ & 35.9 & 22.0 & 71.1 & 36.4 & 9.7 & 0 \\
\hline 10-Oct. & $\mathbf{3 5 . 1}$ & $\mathbf{3 1 . 9}$ & 37.0 & 21.2 & 77.9 & 33.4 & 9.3 & 3.5 \\
\hline
\end{tabular}


Table.4 Correlation matrix for the disease incidence of collar rot of sunflower hybrids in relation to weather parameters

\begin{tabular}{|c|c|c|c|c|c|c|}
\hline \multirow{3}{*}{$\begin{array}{l}\text { Weather } \\
\text { variable }\end{array}$} & \multirow{2}{*}{\multicolumn{2}{|c|}{$\frac{1^{\text {st }} \text { DOS }^{*}(30-6-2014)}{\text { Hybrids }}$}} & \multirow{2}{*}{\multicolumn{2}{|c|}{$\begin{array}{c}2^{\text {nd }} \text { DOS }^{*}(15-7-2014) \\
\text { Hybrids }\end{array}$}} & \multirow{2}{*}{\multicolumn{2}{|c|}{$\begin{array}{c}3^{\text {rd }} \text { DOS }^{*}(1-8-2014) \\
\text { Hybrids }\end{array}$}} \\
\hline & & & & & & \\
\hline & $\begin{array}{c}\text { HSFH- } \\
1183\end{array}$ & $\begin{array}{c}\text { Pioneer } \\
64 \text { A57 }\end{array}$ & $\begin{array}{c}\text { HSFH- } \\
1183\end{array}$ & $\begin{array}{c}\text { Pioneer } \\
64 A 57\end{array}$ & $\begin{array}{c}\text { HSFH- } \\
1183\end{array}$ & $\begin{array}{c}\text { Pioneer } \\
\text { 64A57 }\end{array}$ \\
\hline $\begin{array}{c}\text { Max } \\
\text { temp. }\left({ }^{\circ} \mathrm{C}\right) \\
\left(\mathrm{X}_{1}\right)\end{array}$ & 0.406 & 0.365 & 0.033 & 0.017 & $0.968^{*}$ & $0.963^{* *}$ \\
\hline $\begin{array}{c}\text { Min temp. } \\
\left({ }^{\circ} \mathbf{C}\right) \\
\left(\mathbf{X}_{2}\right)\end{array}$ & $-0.958^{*}$ & $-0.970^{*}$ & $-0.981^{*}$ & $-0.977^{*}$ & $-0.957^{*}$ & $-0.948^{*}$ \\
\hline $\begin{array}{c}\text { Morning } \\
\text { RH(\%) } \\
\left(\mathbf{X}_{3}\right)\end{array}$ & -0.584 & -0.560 & -0.045 & -0.027 & $-0.832^{*}$ & -0.806 \\
\hline $\begin{array}{c}\text { Evening } \\
\text { RH(\%) } \\
\left(\mathbf{X}_{4}\right)\end{array}$ & -0.558 & -0.527 & -0.370 & -0.348 & $-0.951^{*}$ & $-0.938^{*}$ \\
\hline $\begin{array}{c}\text { BSS(hrs) } \\
\left(\mathbf{X}_{5}\right)\end{array}$ & 0.544 & 0.523 & 0.394 & 0.374 & $0.864^{*}$ & $0.842^{*}$ \\
\hline $\begin{array}{c}\text { Rainfall(mm) } \\
\left(\mathbf{X}_{6}\right)\end{array}$ & -0.579 & -0.536 & -0.280 & -0.255 & -0.792 & -0.772 \\
\hline
\end{tabular}

Table.5 Stepwise Regression equation for the disease incidence of collar rot on two hybrids of sunflower in relation to weather parameters under different date of sowing

\begin{tabular}{|c|c|c|}
\hline Hybrids & Regression Equations & $\mathbf{R}^{\mathbf{2}}$ \\
\hline HSFH-1183 & $\mathbf{1}^{\text {st }} \mathbf{D O S}^{*} \mathbf{( 3 0 - 6 - 2 0 1 4 )}$ & \\
\hline Pioneer 64A57 & $\mathrm{Y}=450.21-16.10 \mathrm{X}_{2}-0.17 \mathrm{X}_{6}$ & 0.98 \\
\hline & $\mathrm{Y}=410.75-14.83 \mathrm{X}_{2}-0.12 \mathrm{X}_{6}$ & 0.98 \\
\hline HSFH-1183 & 2nd DOS*(15-7-2014) & 0.96 \\
\hline Pioneer 64A57 & $\mathrm{Y}=112.54-4.12 \mathrm{X}_{2}$ & 0.95 \\
\hline & $\mathrm{Y}=104.01-3.82 \mathrm{X}_{2}$ & \\
\hline HSFH-1183 & 3rd DOS*(1-8-2014) & 0.93 \\
\hline Pioneer 64A57 & $\mathrm{Y}=-262.11+7.96 \mathrm{X}_{1}$ & 0.92 \\
\hline
\end{tabular}

DOS* $=$ Date of sowing

$\mathrm{X}_{1} \quad=$ Temperature Maximum $\left({ }^{\circ} \mathrm{C}\right)$

$\mathrm{X}_{2}=$ Temperature Minimum $\left({ }^{\circ} \mathrm{C}\right)$

$\mathrm{X}_{6}=$ Rainfall $(\mathrm{mm})$ 
Fig.1 Disease incidence in relation to weather parameters in sunflower under first date of sowing (30-06-2014)

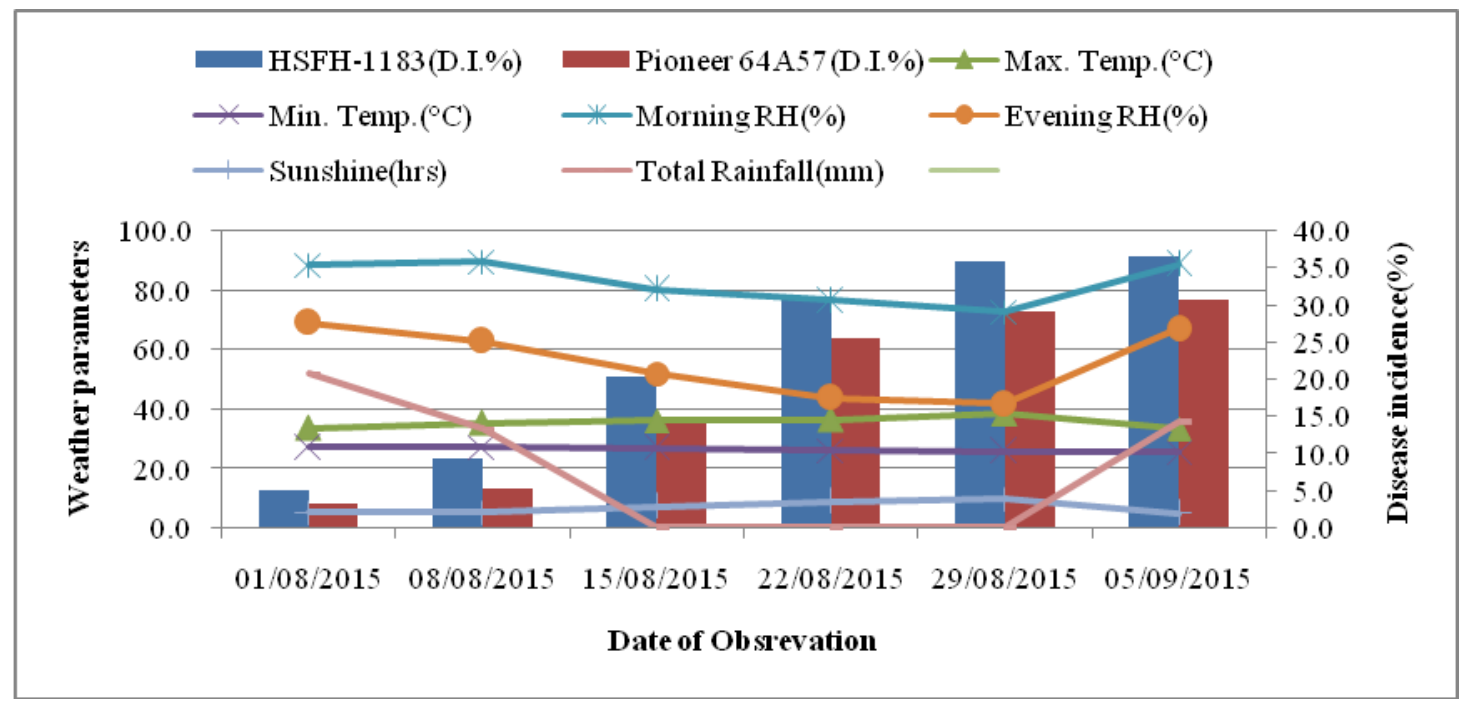

Fig.2 Disease incidence in relation to weather parameters in sunflower under second date of sowing (15-07-2014)

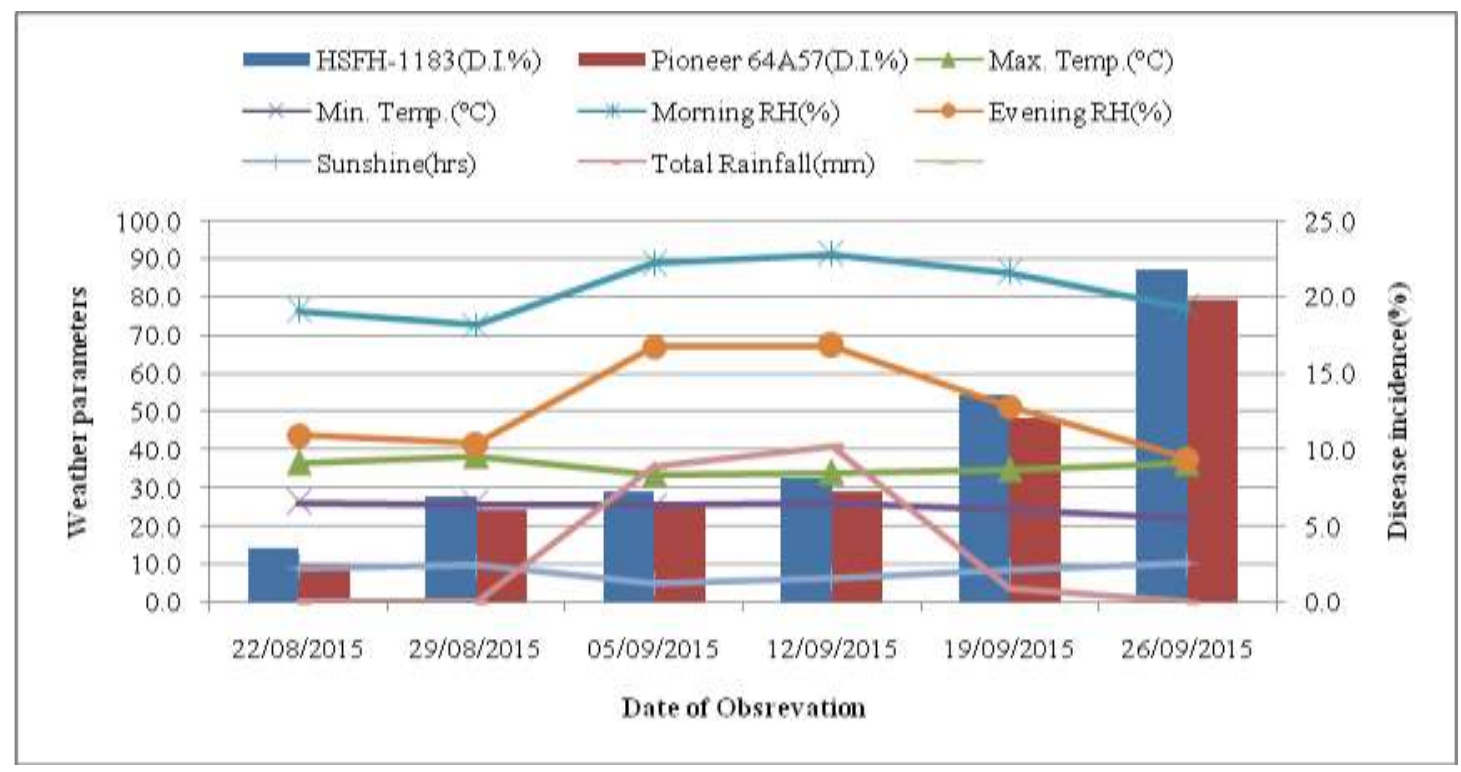


Fig.3 Disease incidence in relation to weather parameter in sunflower under third date of sowing (31-07-2014)

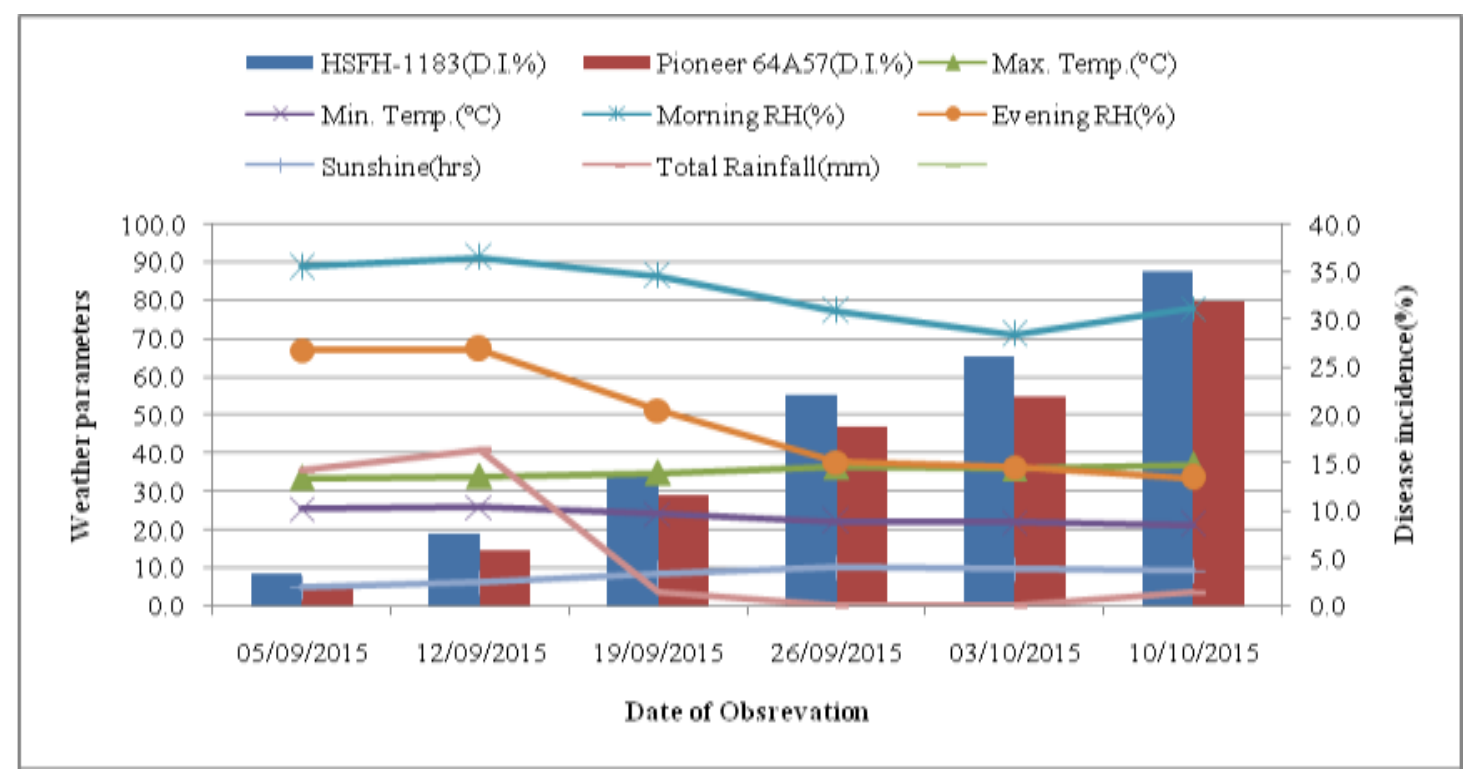

Ten to eleven per cent disease incidence in sunflower crop was also reported when the crop planted in July and August or in February and March in the Nanital Tarai region of Uttar Pradesh (Kolte and Tewari, 1977). Present investigations indicate that sunflower sown by mid July was good to protect the crop from collar rot disease under present conditions. The highest and lowest incidence of collar rot may be correlated with the growth stage of crop. It is evident that 80-90 days of crop growth stage seems to be most susceptible stage for collar rot disease. The importance of this disease stage to overall collar rot epidemics has not been fully identified. Correlations between saprophytic growth and environmental conditions were highly variable and offer little explanation as to the overall role of this disease stage in collar rot epidemics. Further research is needed involving this phenomenon in order to improve the understanding of its relationship to collar rot incidence.

The correlation matrix of weather parameters with the disease incidence revealed negative and significant correlation coefficient ( $p>$
0.05 ) between disease incidence and minimum temperature in both hybrids and all the three date of sowing while positive and significant correlation between disease incidence and maximum temperature was observed during last date of sowing on both hybrids. Further, negative and significant correlation coefficient ( $p>0.05$ ) was observed between disease incidence and relative humidity morning and relative humidity evening during third date of sowing indicating that decrease in relative humidity levels could not check the incidence of collar rot disease development with the passage of season. This indicates that disease development is a cumulative process, once the disease appears, it maintained a gradual but steady increase even temperature was increasing and relative humidity was in decreasing trend with advance of crop season as reported by Mishra and Bhattacharya, (2001) while studying the effect of weather parameters on sigatoka disease of banana. The pathogen is generally prevalent in warm regions of the world and, therefore, has high temperature optimal for its growth and development (Singh et al., 2003). Sunshine hours also play an important role in the 
disease development. In this study there is a positive and significant ( $p>0.05)$ correlation recorded between the disease incidence and sunshine hours during the third date of sowing on both the hybrids. Negative and nonsignificant ( $p>0.05$ ) simple correlation coefficient was observed between disease incidence and rainfall during all date of sowing for both the hybrids. Baniyal et al.,(2008) also reported that the soil moisture level was inversely proportional to collar rot incidence. Devi et al., (1999) also reported better survival of sclerotium rolfsii at low soil moisture levels as compared to high moisture through the optimal level for the development of disease varied to some extent.

\section{References}

Aycock, R. (1966). Stem rot and other disease caused by Sclerotium rolfsii. Technical Bulletin No: 174, North Carolina Agricultural Experimental Station, USA, p. 202.

Anonymous (2013). Directorate of Economics and Statistics, Department of Agriculture, Government of India. 14 February, 2013.

Bandara, J. M. (1980). Effect of soil water potential on the survival of Capsicum annum foot rot fungus in soil. Plant Soil 56: 331-334.

Beute, M. K. and Rodriguez-Kabana, R. (1981). Effect of soil moisture, temperature and field environment on survival of Sclerotium rolfsii in Alabama and North Carolina. Phytopathology 71: 1293-1296.

Chillers, A.J., Herselman L. and Pretorius, Z.A. (2000). Genetic variability within and among mycelia compatibility groups of Sclerotium rolfsii. South Africa Phytopathology, 90: 1026-1031.

Devi, R.K.T., Hifzur, Rahaman., Singh, N.I. and Rahaman, H. (1999). Effect of soil $\mathrm{pH}$, moisture and age of rice seedlings on the incidence of seedling blight caused by Sclerotium rolfsii. Pl. Res. 14: 126-129.

Grichar V J and Bosweel T E (1987), "Comparison of Lorsban and Tilt With Terrachlor For Control of Southern Blight on Peanut the Texas", Agriculture Experiment Station Pr4534.

Javed, Z. U. R. and Coley-Smith, J. R. (1973). Studies on germination of sclerotia of Sclerotium delphinii. Transactions of the British Mycological Society 60: 441-451.

Kolte, S.J. and Tewari, A.N. (1977). Note on effect of planting dates on occurrence and severity of sunflower disease. Journal of Plant Research, 2: 236.

Mihail, J. D. and Alcorn, S. M. (1984). Effects of soil solarization on Macrophomina phaseolina and Sclerotium rolfsii. Plant Disease 68: 156-158.

Mishra, A.K. and Bhattacharyya, A. (2001). Epidemiology and management of sigatoka disease of banana. J. Mycol. Pl. Pathol. 31: 156-164.

Punja, Z. K. and Grogan, R. G. (1981). Mycelial growth and infection without a food base by eruptively germinating sclerotia of Sclerotium rolfsii. Phytopathology 71: 1099-1103.

Punja, Z. K. and Jenkins, S. F. (1984). Influence of temperature, moisture, modified gaseous atmosphere, and depth in soil on eruptive sclerotial germination of Sclerotium rolfsii. Phytopathology 74: 749-754.

Punja, Z.K. (1985). The biology, ecology, and control of Sclerotium rolfsii. Annual Review of Phytopathology, 23: 97-127.

Prasad, S.L., Sujatha MK, Naresh N, Chander Rao S. Variability in Sclerotium rolfsii associated with collar rot of sunflower. Indian Phytopathology. 2012; 65(2):161-165.

Rodriguez-Kabana, R., Backman, P. A. and 
Wiggins, E. A. (1974). Determination of sclerotia populations of Sclerotium rolfsii in soil by a rapid flotationsieving technique. Phytopathology 64: 610-615.

Singh, A., Mehta, S., Singh, H. B. and Nautiyal, C. S. (2003). Biocontrol of collar rot disease of betelvine (Piper betle L.) caused by Sclerotium rolfsii by using rhizosphere-competent Pseudomonas fluorescens NBRI-N6 and $P$. fluorescens NBRI-N. Curr. Microbiol. 47(2): 153-158.

Singh, R., Singh, P.P. and Singh V. (2006). Integrated management of collar rot of Amorphophallus paeonllfolius blume caused by sclerotium rolfsii saccardo. Veg. Sci. (1): 45-49

Smith, A. M. (1972). Drying and wetting sclerotia promotes biological control of Sclerotium rolfsii Sacc. Soil Biology and Biochemistry 4: 119-123.

\section{How to cite this article:}

Vishal Gandhi, R. S. Taya and Anil Kumar. 2019. Epidemiology of Collar Rot of Sunflower (Helianthus annus L.) caused by Sclerotium rolfsii Sacc. Int.J.Curr.Microbiol.App.Sci. 8(10): 762-771. doi: https://doi.org/10.20546/ijcmas.2019.810.088 